\title{
Response of Morphological and Chemical Attributes of Perennial Verbena against Drought Stress
}

\section{Muhammad Ahsan Khatana, Muhammad Muzammil Jahangir*, Choudhary Muhammad Ayyub, Rashad Waseem Khan Qadri*, Muhammad Azam, Khurram Ziaf, Muhammad Awais Ghani, Waseem Iqbal}

Institute of Horticultural Sciences, University of Agriculture, Faisalabad, Pakistan

Email: *muzammil_jahangir@hotmail.com, *waseemrana_83pk@yahoo.com

How to cite this paper: Khatana, M.A., Jahangir, M.M., Ayyub, C.M., Qadri, R.W.K., Azam, M., Ziaf, K., Ghani, M.A. and Iqbal, W. (2018) Response of Morphological and Chemical Attributes of Perennial Verbena against Drought Stress. Open Access Library Journal, 5: e4387. https://doi.org/10.4236/oalib.1104387

Received: January 30, 2018

Accepted: March 12, 2018

Published: March 15, 2018

Copyright $\odot 2018$ by authors and Open Access Library Inc.

This work is licensed under the Creative Commons Attribution International License (CC BY 4.0).

http://creativecommons.org/licenses/by/4.0/

\section{Open Access}

\begin{abstract}
Drought stress is one of the foremost abiotic stresses which causes damage to verbena plant production by affecting its growth and development. There is less information available regarding utilization of perennial verbena under drought conditions. To check the ability of perennial verbena plant under water deficit conditions a pot research trial was planned. Perennial verbena's seeds were sown in plastic trays and applied water daily. When seedlings attained two to three leaves stage then transplanted them into pots and exposed to different intervals of drought. Five drought intervals were applied such as after one day (T0), 4 days (T1), 6 days (T2), 8 days (T3) and 10 days (T4) irrigation intervals. Pots were arranged by adopting completely randomized design with four replications. Many morphological i.e. plant height $(\mathrm{cm})$, root length $(\mathrm{cm})$, number of leaves and flowers/plant, fresh weight of shoot and root $(\mathrm{g})$, dry weight of shoot and root $(\mathrm{g})$ and chemical attributes i.e. chlorophyll "a", "b" and total contents of chlorophyll were examined during this study. The findings exhibited that perennial verbena plant performed best under control conditions while when we increased drought interval gradually from 4 days' interval till 10 days' interval it affected all growth and chemical attributes badly and caused severe damage at 10 days' interval.
\end{abstract}

\section{Subject Areas}

Agricultural Science, Plant Science

\section{Keywords}

Drought Intervals, Abiotic Stresses, Verbena Plant, Chlorophyll Contents, Pot Research Trial 


\section{Introduction}

Drought stress is the process in which plant turgor pressure and water potential is decreased enough and causes water loss, over helming and stomata closure etc. However, in climatic terms drought is a long-term time span in which moisture is less than ordinary in a specific area. It occurs when an area constantly receives less precipitation than normal [1] [2].

World's water reservoirs are at crucial stage and reducing day by day which will be more reduced in coming decades because of global warming [3]. Water requirement is increasing due to increase in world population which needs to focus on drought stress [4]. Pakistan is also affected by drought stress like other countries of world. In Pakistan, most of area comes under arid to semi-arid zone i.e. $0.563 \mathrm{Mkm}^{2}$ area out of $0.804 \mathrm{MKm}^{2}$ is arid land, and annual rain fall is below $60 \mathrm{~cm}$ in area. If annual rain fall is less than required precipitation for crops for a specific period then that area is considered as rain-fed area. Irrigation water is not available throughout the year in Pakistan. One fourth of the total cultivated area (4.9 million ha) of Pakistan is affected by drought stress and it is increasing day by day [5].

Drought stress causes increased infestation of insects, plant' diseases, habitat destruction of wildlife, erosion and quality deterioration of air and water. It also causes many social impacts like conflicts between different countries for water reservoirs, people safety, health and quality of life reduction.

Plants have ability to resist against drought stress and can with stand against drought stress which is called drought resistance [6]. Plant growth and development depends upon cell division, elongation and differentiation which are also affected by water stress [7]. Plants resist against drought stress by adopting different mechanisms i.e. drought escape, avoiding dry spell and tolerance against drought. During drought stress, many functions occur in response to stress i.e. solutes gathering in cells, alteration in osmotic potential by which they naturally tolerate the drought stress [8].

Growers and plant scientists adopt different strategies to cope the problem of drought stress i.e. growing drought tolerant species, use of mulch to avoid water loss and sustainable and wise water use including drip/trickle or sprinkler irrigation system [9].

Among different sustainable tactics introduction and development of different tolerant plant species is an important approach against water deficit condition. Water use efficiency of these plants is $50 \%$ less than other ornamental plants [10]. Verbena is considered one of among those plants which can be grown well under drought circumstances. It is native to America and Asia and member of family verbenaceae.

Due to the different bright colours and fast growth habit verbena flowers can be used for mixed plantation, basket and container plantation. Verbena bloom through out summer. These plants are either annual or perennial depending on winter season. Verbena plants can tolerate summer climate and drought condi- 
tions to some extents. These plants require full sun for proper growth. Flowering and growth is slow under drought conditions [11]. Less information is available regarding use of perennial verbena under drought stress conditions. Due to the beauty and important use of verbena in landscape an experiment was designed to assess the morphological and chemical traits of perennial verbena under drought conditions.

\section{Materials and Methods}

\subsection{Site Description}

This experiment was performed in greenhouse of department of Plant Breeding and Genetics, University of Agriculture, Faisalabad to estimate the water deficit tolerance of perennial verbena.

\subsection{Experimentation}

Perennial verbena seeds were purchased from a local distributor of seed. Seeds were sown in plastic trays by utilizing peat moss as a growing medium and watered daily until seeds were germinated. Then irrigate after one-day interval till transplanting of plants. When seedlings reached at two to three leaves stage, healthy and strong seedlings were transplanted in plastic pots. Size of plastic pots was $24 \mathrm{~cm}$ diameter and $28 \mathrm{~cm}$ depth. Growing media was prepared by mixing leaf compost, sand, F.Y.M and silt at the ratio of 1:1:1:1 and $1400 \mathrm{~g}$ media was filled in each pot. After 15 - 20 days of transplanting when seedlings were well established then applied drought stress treatments.

There were four drought intervals and one control. These drought treatments included T0, T1, T2, T3 and T4 after 1, 4, 6, 8 and 10 days' interval respectively with four replicates. Plants per replicate were 15 and total plants were 60. Plants were observed for 90 days (till death) after drought stress treatments application. After 10 days of drought application data computing was started. After every week, different morphological traits i.e. number of flowers and leaves per plant and plant height $(\mathrm{cm})$ were collected. After every $20^{\text {th }}$ day up to harvesting chlorophyll "a", "b" and total contents of chlorophyll were calculated by adopting method of Davies, 1976. After harvesting of plants, roots were cleaned by distillate water and then calculated the length of roots $(\mathrm{cm})$. Then shoots, roots and leaves were separated and fresh weight of shoots and roots $(\mathrm{g})$ were determined (Mahmood et al., 2008). For calculation of roots and shoots dry weight (g) roots and shoots were separately packed in paper bags and desiccated in oven at $70^{\circ} \mathrm{C}$ to attain persistent weight and then calculated their weight (Mahmood et al., 2008).

\subsection{Statistical Analysis}

Experiment was carried out under CRD (Completely Randomized Design). Data related to different morphological and chemical traits was examined by using analysis of variance (ANOVA) technique by using STATISCA program. The 
mean standards were compared by LSD test at 5\% probability level [12].

\section{Results and Discussion}

Observed data revealed that drought stress significantly affected various morphological and biochemical traits of perennial verbena. All drought intervals significantly affected the number of leaves. Maximum number of leaves (75) were observed at control level, when drought interval increased gradually number of leaves reduced and least leaves number (62.3) were detected at T4 (10 days interval drought interval). The number of leaves at 4, 6 and 8 days' drought interval were between 65 to 70 (Table 1). [13] concluded that Conocarpus erectus leaves number is reduced due to the drought. [14] showed that under drought stress conditions plants growth is effected in contest of plants total leaf area was reduced and more leaf senescence occurred which ultimately had adverse impact on growth. Drought stress drastically affected the photosynthetic rate than respiration rate in higher plants while plant showed resistance against stress by partial or complete stomata closure [15].

Number of flowers was significantly affected by all drought intervals. Number of flowers irrigated at 10 days' interval affected more as compared to daily irrigated plants. Number of flowers decreased gradually from daily to 4, 6, 8 and 10 days' interval Maximum number of flowers (38) were observed under daily irrigation interval while minimum (11) under 10 days interval (Table 1). Our results are in consistent with [14] who reported that variation is occurred in number of flowers during drought condition and caused reduction in growth of plant. Result regarding root length showed that it was significantly affected by water stress. Maximum root length $(12 \mathrm{~cm})$ was observed at one-day interval and it reduced gradually by increasing drought interval from 4 days' interval ( 7 $\mathrm{cm}$ ), followed by 6 days, 8 days and 10 days' irrigation intervals. Minimum root length $(2.5 \mathrm{~cm})$ was observed at 10 days' interval (Table 1). [16] reported that root growth such as length of root, density of root and thick root number reduced when less water is available. [17] observed that long period of water stress

Table 1. Effect of drought stress on morphological attributes of perennial verbena.

\begin{tabular}{|c|c|c|c|c|c|c|c|c|}
\hline Treatments & $\begin{array}{c}\text { Plant height } \\
(\mathrm{cm})\end{array}$ & $\begin{array}{c}\text { Number of } \\
\text { leaves per } \\
\text { plant }\end{array}$ & $\begin{array}{c}\text { Number of } \\
\text { flowers per } \\
\text { plant }\end{array}$ & $\begin{array}{l}\text { Root length } \\
(\mathrm{cm})\end{array}$ & $\begin{array}{l}\text { Root fresh } \\
\text { weight (g) }\end{array}$ & $\begin{array}{l}\text { Shoot fresh } \\
\text { weight (g) }\end{array}$ & $\begin{array}{l}\text { Dry weight } \\
\text { of shoots (g) }\end{array}$ & $\begin{array}{l}\text { Dry weight } \\
\text { of roots (g) }\end{array}$ \\
\hline $\begin{array}{c}\text { (T1) } 4 \text { days } \\
\text { interval }\end{array}$ & $\begin{array}{c}25.575 \pm \\
0.421 \mathrm{~b}\end{array}$ & $\begin{array}{c}74.900 \pm \\
0.325 \mathrm{a}\end{array}$ & $\begin{array}{c}25.500 \pm \\
0.313 \mathrm{~b}\end{array}$ & $\begin{array}{c}6.8750 \pm \\
0.426 \mathrm{~b}\end{array}$ & $\begin{array}{c}4.7500 \pm \\
0.322 \mathrm{~B}\end{array}$ & $\begin{array}{l}9.8750 \pm \\
0.301 \mathrm{ab}\end{array}$ & $\begin{array}{l}5.3750 \pm \\
0.265 \mathrm{ab}\end{array}$ & $\begin{array}{l}2.7750 \pm \\
0.154 \mathrm{ab}\end{array}$ \\
\hline $\begin{array}{c}\text { (T2) } 6 \text { days } \\
\text { interval }\end{array}$ & $\begin{array}{c}23.975 \pm \\
0.248 \mathrm{c}\end{array}$ & $\begin{array}{l}70.900 \pm \\
0.275 \mathrm{bc}\end{array}$ & $\begin{array}{c}25.500 \pm \\
0.361 \mathrm{~b}\end{array}$ & $\begin{array}{c}6.0000 \pm \\
0.292 \mathrm{~b}\end{array}$ & $\begin{array}{l}4.0000 \pm \\
0.414 \mathrm{Bc}\end{array}$ & $\begin{array}{c}9.8750 \pm \\
0.426 \mathrm{~b}\end{array}$ & $\begin{array}{l}4.6000 \pm \\
0.334 \mathrm{bc}\end{array}$ & $\begin{array}{l}2.2250 \pm \\
0.170 \mathrm{bc}\end{array}$ \\
\hline $\begin{array}{c}\text { (T3) } 8 \text { days } \\
\text { interval }\end{array}$ & $\begin{array}{c}23.675 \pm \\
0.149 c\end{array}$ & $\begin{array}{l}67.550 \pm \\
0.283 \mathrm{~cd}\end{array}$ & $\begin{array}{c}15.750 \pm \\
0.478 \mathrm{c}\end{array}$ & $\begin{array}{c}4.0025 \pm \\
0.339 c\end{array}$ & $\begin{array}{c}3.8000 \pm \\
0.195 \mathrm{C}\end{array}$ & $\begin{array}{c}5.7500 \pm \\
0.095 c\end{array}$ & $\begin{array}{l}3.4500 \pm \\
0.366 \mathrm{~cd}\end{array}$ & $\begin{array}{c}1.9750 \pm \\
0.103 \mathrm{c}\end{array}$ \\
\hline $\begin{array}{c}\text { (T4) } 10 \text { days } \\
\text { interval }\end{array}$ & $\begin{array}{c}22.425 \pm \\
0.469 \mathrm{~d}\end{array}$ & $\begin{array}{c}65.300 \pm \\
0.295 \mathrm{~d}\end{array}$ & $\begin{array}{c}13.000 \pm \\
0.278 c\end{array}$ & $\begin{array}{c}3.2500 \pm \\
0.322 \mathrm{c}\end{array}$ & $\begin{array}{c}2.0000 \pm \\
0.248 \mathrm{D}\end{array}$ & $\begin{array}{c}3.8750 \pm \\
0.184 \mathrm{c}\end{array}$ & $\begin{array}{c}2.1250 \pm \\
0.252 \mathrm{~d}\end{array}$ & $\begin{array}{c}1.1000 \pm \\
0.313 \mathrm{~d}\end{array}$ \\
\hline
\end{tabular}

Means values donating by different letters are significantly differ from each other at $5 \%$ probability level within columns. 
reduced growth of populous species and biomass of fibrous root system in Avocado. [18] [19] studied that during dry soil conditions root length is suppressed but less effected as compared to shoots which alter the root shoot ratio. Data regarding root fresh weight showed significant difference during water stress. Maximum root fresh weight $(6.5 \mathrm{~g})$ was observed at one-day interval, then gradually decreased at 4, 6, 8 days' interval and maximum decrease was observed at 10 days' intervals which was double than preceding one (Table 1). Our findings were similar with [20] who found $1 / 3$ rd reduction in size of fresh weight of roots under drought, in Ziziphus rotundifolia.

Impact of water stress was significantly observed on root dry weight. Maximum root dry weight $(4.3 \mathrm{~g})$ was observed at daily irrigation interval and minimum (0.4 g) at 10 days' interval (Table 1). [19] showed that root dry weight was reduced in response of drought stress. The results regarding shoot fresh weight were showed that shoot fresh weight is reduced by increasing drought interval period. Maximum shoot weight (14 g) was observed under daily irrigation interval while weight decreased drought interval increased i.e. $8.5 \mathrm{~g}$ and $7 \mathrm{~g}$ at 4 days' interval and 6 days' interval respectively. Minimum shoot fresh weight (3 g) was observed at 10 days' interval (Table 1). Our results are consistent with the findings of [21] which showed that drought reduced the fresh weight of roots of Populus davidiana and it also reduced root growth and other growth traits of Populus cathayami. [22] concluded that plant leaves area, height and biomass was reduced and negative correlation observed of head diameter with fresh shoot and root weights under water deficit conditions. Shoot dry weight affected significantly by drought stress. Shoot dry weight decreased by increasing drought intervals from daily till 10 days' interval. Maximum shoot dry weight $(7.9 \mathrm{~g})$ was observed at control treatment i.e. daily irrigation interval while minimum weight $(1.5 \mathrm{~g})$ observed at 10 days' interval (Table 1). [23] observed that under drought stress condition shoot dry weight of different sugar beet cultivars significantly affected while loss in dry weight of shoot is more than dry weight of root. Drought has significant effect on height of plants. Maximum height of plant $(28.6 \mathrm{~cm})$ was observed at control treatment and then decreased gradually from 4 days' interval till 10 days interval $(21.2 \mathrm{~cm}$ ) (Table 1). [24] concluded that stem height of many trees like Casuarina cunmnehamiana and Eucalyptus camaldulensis reduced against drought conditions. [25] explained that stem height of Abelmoschusesculentus is reduced due to the senescence of leaves and reduction in cell enlargement in response of drought.

Chlorophyll "a" contents reduced by increasing drought interval from daily to 4, 6, 8 and 10 days' interval. Highest contents of chlorophyll "a" $(3.10 \mathrm{mg} / \mathrm{g})$ were detected at T0 (one-day interval) while minimum $(0.68 \mathrm{mg} / \mathrm{g}$ ) were observed at T4 (10 days' interval) (Table 2). Chlorophyll "b" contents also significantly affected by drought stress. Maximum chlorophyll contents $(1.52 \mathrm{mg} / \mathrm{g})$ were observed at daily irrigation interval and then chlorophyll contents decreased gradually by increasing drought interval i.e. $1.23 \mathrm{mgg}-1,0.54 \mathrm{mgg}-1$ and 0.46 mgg- 1 at 4,8 and 10 days' interval respectively (Table 2 ). Total chlorophyll 
Table 2. Effect of drought stress on chemical attributes of perennial verbena.

\begin{tabular}{cccc}
\hline Treatments & $\begin{array}{c}\text { Chlorophyll “a” } \\
\left(\mathbf{m g} \cdot \mathbf{g}^{-1}\right)\end{array}$ & $\begin{array}{c}\text { Chlorophyll "b" } \\
\left(\mathbf{m g} \cdot \mathbf{g}^{-1}\right)\end{array}$ & $\begin{array}{c}\text { Total Chlorophyll contents } \\
\left(\mathbf{m g} \cdot \mathbf{g}^{-1}\right)\end{array}$ \\
\hline (To) Control & $2.8075 \pm 0.109 \mathrm{a}$ & $1.4750 \pm 0.029 \mathrm{a}$ & $4.2825 \pm 0.089 \mathrm{a}$ \\
(T1) 4 days interval & $2.1950 \pm 0.076 \mathrm{~b}$ & $1.0925 \pm 0.053 \mathrm{~b}$ & $3.2875 \pm 0.128 \mathrm{~b}$ \\
(T2) 6 days interval & $1.4100 \pm 0.094 \mathrm{c}$ & $0.8200 \pm 0.047 \mathrm{c}$ & $2.2300 \pm 0.139 \mathrm{c}$ \\
(T3) 8 days interval & $1.1675 \pm 0.110 \mathrm{~cd}$ & $0.6175 \pm 0.035 \mathrm{~d}$ & $1.7850 \pm 0.128 \mathrm{~d}$ \\
(T4) 10 days interval & $0.9050 \pm 0.075 \mathrm{~d}$ & $0.5375 \pm 0.030 \mathrm{~d}$ & $1.4425 \pm 0.084 \mathrm{~d}$ \\
\hline
\end{tabular}

Means values donating by different letters are significantly different from each other at 5\% probability level within columns.

contents were reduced by increasing drought interval. Maximum total chlorophyll contents $(4.49 \mathrm{mg} / \mathrm{g})$ were observed at control treatment then these were gradually decreased $(3.61 \mathrm{mg} / \mathrm{g}, 1.54 \mathrm{mg} / \mathrm{g}$ and $1.22 \mathrm{mg} / \mathrm{g}$ at 4,8 and 10 days' interval respectively) by increasing drought interval (Table 2). Nyachiro et al., 2001 also found that chlorophyll a and b contents of six Triticum aestivum genotypes were significantly decreased due to the water deficit conditions. [26] reported that drought stress applied at vegetative growth stage or anthesis decreased chloropyll contents ( $\mathrm{a}, \mathrm{b}$ and total). Photosynthetic pigments (chlorophyll a, b, and total contents) plays an important role in photosynthetic process. Under extreme drought stress conditions stomata functioning is altered which effect photosynthesis and $\mathrm{CO}_{2}$ uptake which cause different chlorophyll contents level during whole growing period of plant [27] [28]. Severe and prolonged drought period cause variation in chlorophyll synthesis rate, chloroplast structural and functional changes and acclimatization and transfer of products in various parts of plants [29]. Drought stress severely affects chlorophyll contents which showed variation at different growth stages [27].

\section{Conclusion}

From above results, it is concluded that there was decreasing trend in morphological traits with increasing irrigation intervals. Flowers and leaves number per plant, root shoot length and height of plant were decreased. Fresh and dry weight of roots and shoots was decreased when drought intervals increased gradually. Results regarding chemical traits i.e. chlorophyll a, b and total contents were decreased by increasing drought intervals. Overall results exhibited that water deficit conditions have adverse effect on morphology and chemical contents of perennial verbena.

\section{References}

[1] Chaves, M.M., Maroco, J.P. and Pereira, J.S. (2003) Understanding Plant Responses to Drought-From Genes to the Whole Plant. Functional Plant Biology, 30, 239-264. https://doi.org/10.1071/FP02076

[2] Jaleel, C., Gopi, R., Manivannan, P., Kishorekumar, A., Sankar, B. and Panneerselvam, R. (2006) Paclobutrazol Influences on Vegetative Growth and Floral Characteristics of Catharanthus roseus (L.) G. Don. Indian Journal of Applied \& Pure Biolo- 
gy, 21, 369-372.

[3] Salinger, M.J. (2005) Climate Variability and Change: Past, Present and Future-An Overview. In: Increasing Climate Variability and Change, Springer, Berlin, 9-29. https://doi.org/10.1007/1-4020-4166-7_3

[4] Somerville, C. and Briscoe, J. (2001) Genetic Engineering and Water. American Association for the Advancement of Science, Washington DC.

[5] Khan, A.R. and Qayyum, A. (1986) Management of Rainfed Farming. Progressive Farming (Pakistan), 6, 6-14.

[6] Beard, J. and Sifers, S. (1997) Genetic Diversity in Dehydration Avoidance and Drought Resistance within the Cynodon and Zoysia Species. International Turf Grass Society Research Journal, 8, 603-610.

[7] Patel, M. and Golakiya, B. (1988) Effect of Water-Stress on Yield Attributes and Yield of Groundnut (Arachis-Hypogaea). Indian Journal of Agricultural Sciences, New Delhi, 701-703.

[8] Ashraf, M. and Yasmin, N. (1997) Response of Some Arid Zone Grasses to Brakish Water. Der Tropenlandwirt-Journal of Agriculture in the Tropics and Subtropics, 98, 3-12.

[9] Anjum, S.A., Xie, X.-Y., Wang, L.-C., Saleem, M.F., Man, C. and Lei, W. (2011) Morphological, Physiological and Biochemical Responses of Plants to Drought Stress. African Journal of Agricultural Research, 6, 2026-2032.

[10] Gilman, E.F. and Howe, T. (1999) Tagetes erecta, Fact Sheet FPS-569. Institute of Food and Agricultural Science, University of Florida, Gainesville.

[11] Carvalho, S.M., Eveleens-Clark, B., Bakker, M. and Heuvelink, E. (2006) Improving Product Quality and Timing of Kalanchoe: Model Development and Validation. ActaHortic, 718, 655-662. https://doi.org/10.17660/ActaHortic.2006.718.76

[12] Steel, R.G., Torrie, J.H. and Dickey, D.A. (1997) Principles and Procedures of Statistics: A Biological Approach. McGraw-Hill, New York.

[13] El-Juhany, L.I. and Aref, I.M. (1999) Groth and Dry Matter Partitioning of Leucaena leucocephala (Lam.) De Wit. Trees as Affected by Water Stress. Alexandria Journal of Agricultural Research, 44, 237-260.

[14] Basra, A. (1997) Mechanisms of Environmental Stress Resistance in Plants. CRC Press, Boca Raton.

[15] Sundaravalli, V., Paliwal, K. and Ruckmani, A. (2005) Effect of Water Stress on Photosynthesis, Protein Content and Nitrate Reductase Activity of Albizzia Seedlings. Journal of Plant Biology-New Delhi, 32, 13.

[16] Passioura, J. (1981) The Role of Root System Characteristics in Drought Resistance of Crop Plants. In: Drought Resistance in Crops with Emphasis on Rice, IRRI, Laguna, 71-82.

[17] Singh, T., Paleg, I. and Aspinall, D. (1973) Stress Metabolism III. Variations in Response to Water Deficit in the Barley Plant. Australian Journal of Biological Sciences, 26, 65-76.

[18] Wang, H. (2006) Growth and Function of Roots under Abiotic Stress in Soil. In: Huang, B., Ed., Plant-Environment Interactions, 3rd Edition, CRC Press, New York, 271-320.

[19] Yin, C., Wang, X., Duan, B., Luo, J. and Li, C. (2005) Early Growth, Dry Matter Allocation and Water Use Efficiency of Two Sympatric Populus Species as Affected by Water Stress. Environmental and Experimental Botany, 53, 315-322. https://doi.org/10.1016/j.envexpbot.2004.04.007 
[20] Tsialtas, J., Handley, L., Kassioumi, M., Veresoglou, D. and Gagianas, A. (2001) Interspecific Variation in Potential Water-Use Efficiency and Its Relation to Plant Species Abundance in a Water-Limited Grassland. Functional Ecology, 15, 605-614. https://doi.org/10.1046/j.0269-8463.2001.00555.x

[21] Willekens, H., Inzé, D., Van Montagu, M. and Van Camp, W. (1995) Catalases in Plants. Molecular Breeding, 1, 207-228. https://doi.org/10.1007/BF02277422

[22] Tahir, M.H.N. and Mehid, S. (2001) Evaluation of Open Pollinated Sunflower (Helianthus annuus L.) Populations under Water Stress and Normal Conditions. International Journal of Agriculture and Biology, 3, 236-238.

[23] Zhang, X., Zang, R. and Li, C. (2004) Population Differences in Physiological and Morphological Adaptations of Populus davidiana Seedlings in Response to Progressive Drought Stress. Plant Science, 166, 791-797.

https://doi.org/10.1016/j.plantsci.2003.11.016

[24] Sun, D. and Dickinson, G.R. (1995) Salinity Effects on Tree Growth, Root Distribution and Transpiration of Casuarina cunninghamiana and Eucalyptus camaldulensis Planted on a Saline Site in Tropical North Australia. Forest Ecology and Management, 77, 127-138. https://doi.org/10.1016/0378-1127(95)03568-U

[25] Manivannan, P., Jaleel, C., Kishorekumar, A., Sankar, B., Somasundaram, R., Sridharan, R. and Panneerselvam, R. (2007) Propiconazole Induced Changes in Antioxidant Metabolism and Drought Stress Amelioration in Vigna unguiculata (L.) Walp. Colloids and Surfaces B: Biointerfaces, 57, 69-74. https://doi.org/10.1016/j.colsurfb.2007.01.004

[26] Mafakheri, A., Siosemardeh, A., Bahramnejad, B., Struik, P. and Sohrabi, Y. (2010) Effect of Drought Stress on Yield, Proline and Chlorophyll Contents in Three Chickpea Cultivars. Australian Journal of Crop Science, 4, 580-585.

[27] Flexas, J. and Medrano, H. (2002) Drought-Inhibition of Photosynthesis in C3 Plants: Stomatal and Non-Stomatal Limitations Revisited. Annals of Botany, 89, 183-189. https://doi.org/10.1093/aob/mcf027

[28] Begg, J.E. and Turner, N.C. (1976) Crop Water Deficits. Advances in Agronomy, 28, 161-217. https://doi.org/10.1016/S0065-2113(08)60555-6

[29] Medrano, H., Escalona, J., Bota, J., Gulias, J. and Flexas, J. (2002) Regulation of Photosynthesis of C3 Plants in Response to Progressive Drought: Stomatal Conductance as a Reference Parameter. Annals of Botany, 89, 895-905.

https://doi.org/10.1093/aob/mcf079 